\title{
Supramolecular Host-Guest Chemistry-Based Folate/Riboflavin Functionalization and Cancer Cell Labeling of Nanoparticles
}

\author{
Suman Pal, $\odot$ Chumki Dalal, $\odot$ and Nikhil R. Jana*๑ \\ Centre for Advanced Materials, Indian Association for the Cultivation of Science, 2A \& 2B Raja S. C. Mullick Road, Kolkata 700032, \\ India
}

Supporting Information

\begin{abstract}
Nanoparticle-based cellular probes are commonly designed via covalent conjugation with affinity biomolecules. Those nanobioconjugates selectively interact with cell surface receptors and induce endocytosis followed by intracellular trafficking. However, this approach requires functional modification of biomolecules that may alter their biochemical activity. Here, we show that supramolecular host-guest chemistry can be utilized as an alternative approach in nanoparticle functionalization and selective cell labeling. We have used cyclodextrin-conjugated quantum dots (QDs) for supramolecular host-guest interaction-based functionalization with folate (QD-folate) and riboflavin (QD-riboflavin), where cyclodextrin acts as a host for the folate/ riboflavin guest. We demonstrate that QD-folate and QD-riboflavin selectively label cells that have over-expressed folate/riboflavin receptors and induce the endocytosis pathway similar to covalently conjugated folate-/riboflavin-based nanoprobes. However, labeling is highly sensitive to the molar ratio of folate/riboflavin to

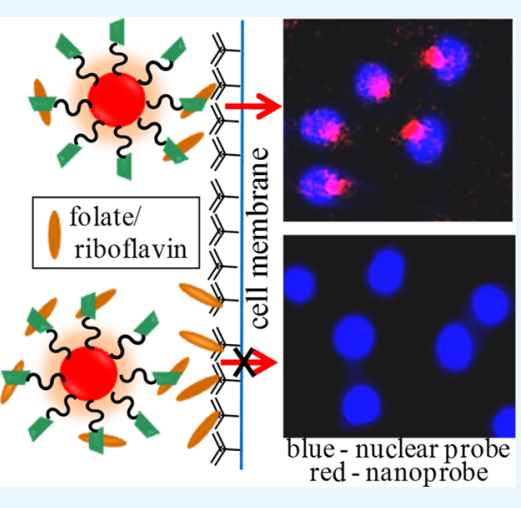
cyclodextrin and incubation time. The presented functionalization/labeling approach is unique as it does not require covalent conjugation and may be extended for in vivo targeting application via simultaneous delivery of host and guest molecules.
\end{abstract}

\section{INTRODUCTION}

Nanoparticles are widely used as imaging probes, drug delivery carriers, single-molecule tracking probes and theranostic agents. ${ }^{1-6}$ In these applications, nanoparticles are transformed into functional nanoparticles or nanobioconjugates for selective targeting/labeling of tissues, cells, and biomolecules. ${ }^{7-9}$ Usual functionalization approaches involve covalent conjugation of nanoparticles with affinity biomolecules such as vitamin, oligonucleotides, aptamers, peptides, antibodies, and carbohydrates. $^{7-9}$ Variety of bioconjugation reagents along with conjugation protocols are now commercially available, which are routinely exploited in deriving functional nanoparticles. ${ }^{7-10}$ However, there are few limitations in such a covalent conjugation approach that include loss of biochemical activity of affinity biomolecules because of covalent conjugation, specialized chemistry involved in each type of functionalization, and difficulty in purification of functionalized nanoprobes. ${ }^{7-10}$ Thus, research has been directed toward advanced and alternative approaches of functionalization. ${ }^{11-15}$

Supramolecular host-guest interaction can be viewed as a unique alternative for functionalization as it does not involve any covalent modification. ${ }^{16-24}$ In the host-guest interaction, the hydrophobic cavity of cyclodextrin (CD), cucurbituril, and calixarene can incorporate guest molecules (or a part of guest molecules) via noncovalent and weak interactions. ${ }^{25-28}$ Such host-guest interaction has been successfully utilized for functionalization of 2D surfaces, ${ }^{16,17}$ nanoparticles, ${ }^{19-24}$ cell membranes, ${ }^{18}$ and polymers/dendrimers. ${ }^{25-28}$ Moreover, such type of functional materials have been used in drug delivery, ${ }^{26,28}$ biosensing, ${ }^{2-31}$ and other biomedical applications. $^{26}$ However, in all these host-guest approaches, only selected host-guest molecules (e.g. CD-adamantane, and $\mathrm{CD}-$ ferrocene) are used to produce stronger interactions. In reality, many of the host-guest interactions are weak/ reversible, unstable in the presence of competitor molecules and difficult to be utilized for biomedical applications. ${ }^{25-28}$ In particular, the reversible host-guest interaction limits functionalization of polymers/nanoparticles with vitamins/carbohydrates/peptides and shrinks the scope for selective targeting/ labeling applications under a complex bioenvironment. Here, we demonstrate that the reversible host-guest interaction between the $\mathrm{CD}$ host and the folate/riboflavin guest can be exploited for the functionalization of nanoparticles and targeting cancer cells followed by cellular endocytosis and subcellular trafficking. It is known that folate and riboflavin receptors are over-expressed in several types of cancer cells and their covalent conjugates with polymers/nanoparticles/CD are used for targeting cancer cells. ${ }^{32-36}$ However, the host-guest interaction-based functionalization of folate/riboflavins is not extensively utilized in cell targeting, except in one report and without details of the uptake mechanism. ${ }^{19}$ This is because of weaker host-guest interaction as compared to CD-adaman-

Received: October 7, 2017

Accepted: November 30, 2017

Published: December 14, 2017 
Scheme 1. Synthetic Approach for the Preparation of $\mathrm{QD}(\mathrm{CD})_{70}$ from $\mathrm{QD}\left(\mathrm{NH}_{2}\right)_{100}$ and Transformation into Folate-/ Riboflavin-Functionalized QDs via the Host-Guest Interaction ${ }^{a}$
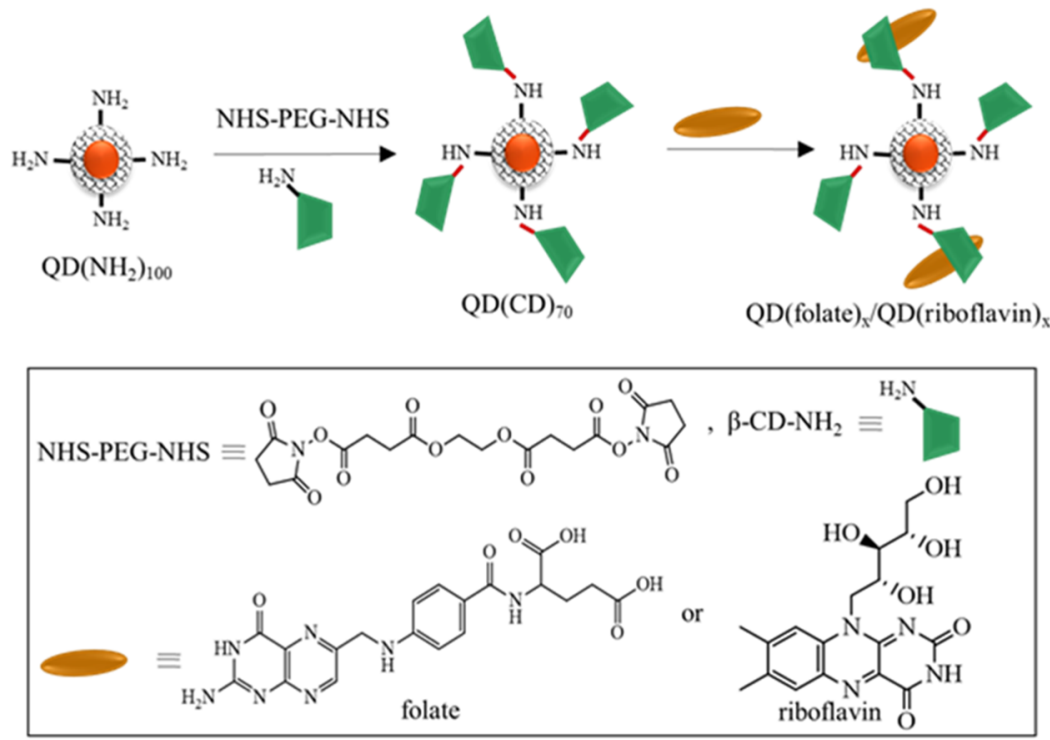

${ }^{a}$ Hydrophilic $\mathrm{QD}\left(\mathrm{NH}_{2}\right)_{100}$ is prepared from hydrophobic QD via the polyacrylate coating that has $\sim 100$ average number of primary amines per particle. Next, $\mathrm{QD}\left(\mathrm{NH}_{2}\right)_{100}$ is covalently conjugated with $\beta-\mathrm{CD}-\mathrm{NH}_{2}$ to produce $\mathrm{QD}(\mathrm{CD})_{70}$ that has $\sim 70$ average number of $\mathrm{CDs}$ per particle. Colloidal $\mathrm{QD}(\mathrm{CD})_{70}$ is incubated with varied concentrations of folate/riboflavin to produce folate-/riboflavin-functionalized $\mathrm{QDs}$ (i.e. $\mathrm{QD}\left(\mathrm{folate}_{x}\right.$ and $\left.\mathrm{QD}(\text { riboflavin })_{x}\right)$, where " $x$ " denotes the average number of folate/riboflavin per particle in the range of $1-35$.
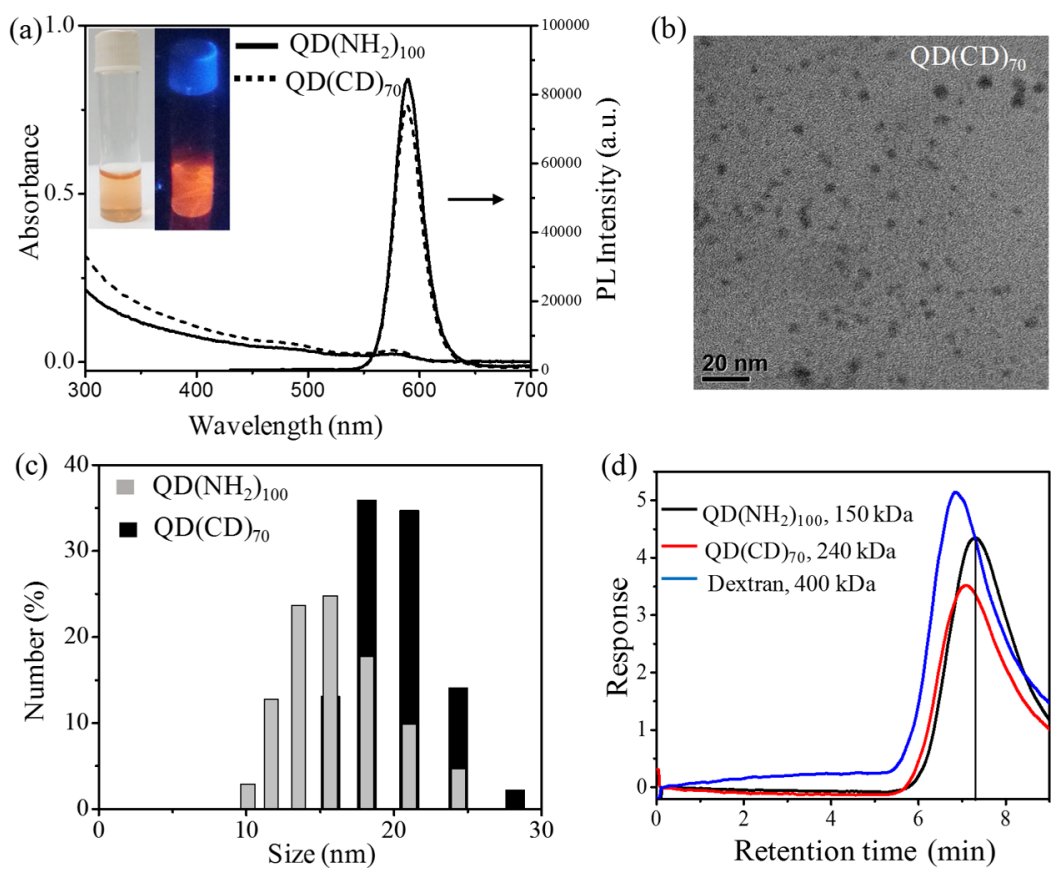

Figure 1. (a) UV-visible and fluorescence spectra of $\mathrm{QD}\left(\mathrm{NH}_{2}\right)_{100}$ and $\mathrm{QD}(\mathrm{CD})_{70}$. Inset shows the colloidal solution of $\mathrm{QD}(\mathrm{CD})_{70}$ under normal (left) and UV light (right). (b) TEM image of $\mathrm{QD}(\mathrm{CD})_{70}$ showing the inorganic $\mathrm{QD}$ core of 4-5 nm size. (c) Hydrodynamic size of $\mathrm{QD}\left(\mathrm{NH}_{2}\right)_{100}$ and $\mathrm{QD}(\mathrm{CD})_{70}$. (d) GPC-based determination of molecular weights of $\mathrm{QD}\left(\mathrm{NH}_{2}\right)_{100}$ and $\mathrm{QD}(\mathrm{CD})_{70}$, showing that the molecular weight increases by $90 \mathrm{kDa}$ after functionalization with $\mathrm{CD}$.

tane or CD-ferrocene. ${ }^{37-39}$ Here, we show that quantum dots (QDs) functionalized with folate/riboflavin via the host-guest interaction can successfully label cells that have over-expressed folate/riboflavin receptors and induce the endocytosis pathway similar to nanoprobes that have covalently conjugated folate/ riboflavin. However, labeling is highly sensitive to the ratio of folate/riboflavin to $\mathrm{CD}$ and incubation time.

\section{RESULTS}

Synthesis of CD-Functionalized QDs $\left[\mathrm{QD}(\mathrm{CD})_{70}\right]$. We have synthesized $\beta$-CD-functionalized $Q D s$ with an average number of $70 \mathrm{CD}$ per $\mathrm{QD}$ (i.e. $\mathrm{QD}(\mathrm{CD})_{70}$ ) and used them in deriving folate- and riboflavin-functionalized QDs (Scheme 1). Hydrophobic QDs are transformed into polyacrylate-coated hydrophilic QDs with an average of 100 primary amine groups 

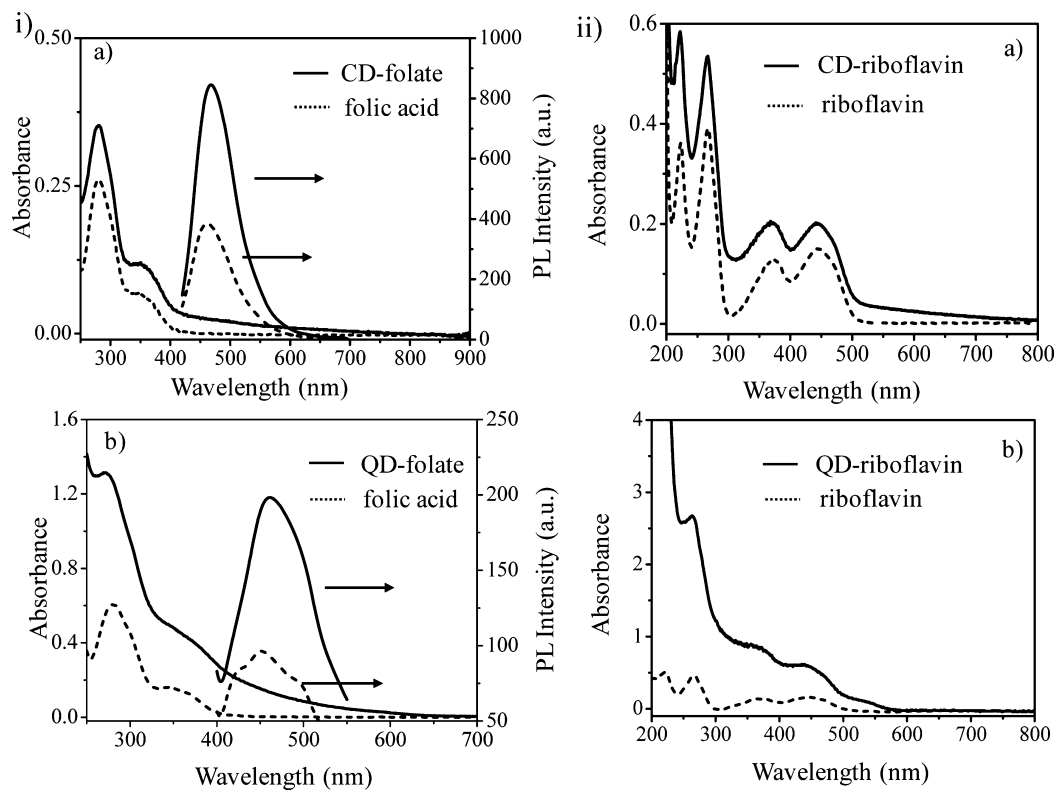

Figure 2. (i) Evidence of the host-guest interaction of folate with $\beta$-CD (a) and $\mathrm{QD}(\mathrm{CD})_{70}(\mathrm{~b})$. Same concentration of folic acid is incubated with $\beta$ - $\mathrm{CD}-\mathrm{NH}_{2} / \mathrm{QD}(\mathrm{CD})_{70}$, where the molar ratio of folate to $\mathrm{CD}$ is maintained as $1: 20$, and then, the absorption/emission spectra of folate is measured. Results show that the host-guest interaction leads to increased absorbance at 360 and $280 \mathrm{~nm}$ and increased emission spectra at $455 \mathrm{~nm}$. For the $\mathrm{QD}(\mathrm{CD})_{70}$ sample, $\mathrm{QDs}$ are dissolved by $\mathrm{HCl}$ followed by neutralization with a base prior to spectral measurements. (ii) Evidence of the host-guest interaction of riboflavin with $\beta$-CD (a) and $\mathrm{QD}(\mathrm{CD})_{70}$ (b) Same concentration of riboflavin is incubated with $\beta$ - $\mathrm{CD}-\mathrm{NH} \mathrm{H}_{2} / \mathrm{QD}(\mathrm{CD})_{70}$, where the molar ratio of riboflavin to $\mathrm{CD}$ is maintained as $1: 30$, and then, the absorption spectra of riboflavin is measured.

per QD. ${ }^{11}$ In this coating, four acrylates are used that include poly(ethylene glycol) methacrylate that provides the pegylated surface, $\mathrm{N}$-(3-aminopropyl)-methacrylamide that introduces primary amine groups on the polymer shell, 3-sulfopropyl methacrylate that introduces $\mathrm{SO}_{3}{ }^{-}$groups, and bis[2(methacryloyloxy)ethyl] phosphate that crosslinks the polymer shell. In addition, four acrylates are used in appropriate molar ratios to minimize particle-particle cross-linking. The primary amines are estimated via the fluorescamine test; the QD concentration is determined from their respective molar extinction coefficient ${ }^{40}$ and the QDs are designated as $\mathrm{QD}\left(\mathrm{NH}_{2}\right)_{100}$ as the number of primary amines per $\mathrm{QD}$ is $\sim 100$ (Supporting Information, Figure S1). Next, $\mathrm{QD}\left(\mathrm{NH}_{2}\right)_{100}$ is transformed into CD-functionalized $\mathrm{QDs}$ by conjugating $\beta$ $\mathrm{CD}-\mathrm{NH}_{2}$ using ethylene glycol-bis(succinic acid- $\mathrm{N}$-hydroxysuccinimide ester) (NHS-PEG-NHS) as the conjugation reagent. Typically, $\beta$-CD-NH $\mathrm{NH}_{2}$ and NHS-PEG-NHS are mixed in 1:1 molar ratio for reaction of the primary amine of $\mathrm{CD}-\mathrm{NH}_{2}$ with one NHS of NHS-PEG-NHS. Next, the $\mathrm{QD}\left(\mathrm{NH}_{2}\right)_{100}$ solution is mixed with the excesses (10 times of primary amines present in the QDs) of this solution and under this condition other NHS of NHS-PEG-NHS react with primary amines of QDs. Next, excesses of reagents are removed via dialysis (molecular weight cut-off: $12 \mathrm{kDa}$ ) against fresh water. The amount of QD-bound $\mathrm{CD}$ is estimated by the anthrone test, and the number of $\mathrm{CD}$ per $\mathrm{QD}$ is estimated to be $\sim 70$ and designated as $\mathrm{QD}(\mathrm{CD})_{70}$ (Figure 1 and Supporting Information, Figure $S 1)$. This number of $C D$ per $Q D$ has been further confirmed from the gel permeation chromatography (GPC)-based molecular weight study and the fluorescamine test of $\mathrm{QD}\left(\mathrm{NH}_{2}\right)_{100}$ and $\mathrm{QD}(\mathrm{CD})_{70}$ (Figure 1). The GPC results show that the molecular weight is increased by $90 \mathrm{kDa}$ after the transformation of $\mathrm{QD}\left(\mathrm{NH}_{2}\right)_{100}$ to $\mathrm{QD}(\mathrm{CD})_{70}$ which corresponds to $\sim 70 \mathrm{CD}$. Estimation of primary amines (via fluorescamine test) in $\mathrm{QD}\left(\mathrm{NH}_{2}\right)_{100}$ and $\mathrm{QD}(\mathrm{CD})_{70}$ also corroborates this value (Supporting Information, Figure S1). The transmission electron microscopy (TEM) image of $\mathrm{QD}(\mathrm{CD})_{70}$ shows that the $\mathrm{QD}$ core is of $4-5 \mathrm{~nm}$ size, the dynamic light scattering (DLS) study shows $15-25 \mathrm{~nm}$ hydrodynamic size, and the zeta potential data show -10 to $-20 \mathrm{mV}$ charge at $\mathrm{pH} 7.4$ (Figure 1).

Host-Guest Chemistry-Based Synthesis of Folateand Riboflavin-Functionalized QDs. Folate and riboflavin functionalization of $\mathrm{QD}(\mathrm{CD})_{70}$ is performed via the host-guest interaction using folate/riboflavin as the guest for CDs. Typically, solution of folic acid/riboflavin is mixed to the solution of $\mathrm{QD}(\mathrm{CD})_{70}$ and incubated in water at room temperature overnight under dark condition. The molar ratio of QD-bound CD to folate/riboflavin is varied in a large range typically from 1 to 70 to optimize the functionalization. Under this condition, folate/riboflavin is noncovalently incorporated inside the hydrophobic cavity of $\mathrm{CD}$. We have studied this host-guest interaction using $\mathrm{QD}(\mathrm{CD})_{70}$ and compared with $\beta$ $\mathrm{CD}-\mathrm{NH}_{2}$ (Figure 2 and Supporting Information, Figure S2). Host-guest interaction leads to the increased absorption/ emission band of folate/riboflavin, similar to $\mathrm{CD}-$ folate $^{39}$ and $\mathrm{CD}$-riboflavin systems. ${ }^{37,38}$ Folic acid and riboflavin make inclusion complex by incorporating their hydrophobic part into the hydrophobic cavity of $\beta$-CD. This fact restricts their vibrational rotation, leading to significant increment in absorbance and fluorescence. ${ }^{38}$ Considering the reasonably high association constant for this type host-guest complexation (in the order of $\left.10^{5}-10^{6} \mathrm{M}^{-1}\right)^{37-39}$ and 1-70 molar ratio of $\mathrm{CD}$ to folate/riboflavin used it can be assumed that most of the folate/riboflavin are bound to $\mathrm{CD}$ at the 10-50 molar ratio and some of them may be free at the 1-5 molar ratio. In addition, the number of folate/riboflavin bound on each QD may vary from 1 to 35 as the molar ratio of CD to folate/riboflavin is varied from 50 to 2 . As the binding constant between $C D$ and folate/riboflavin is comparable to the used concentrations of 
a)


f)


b)
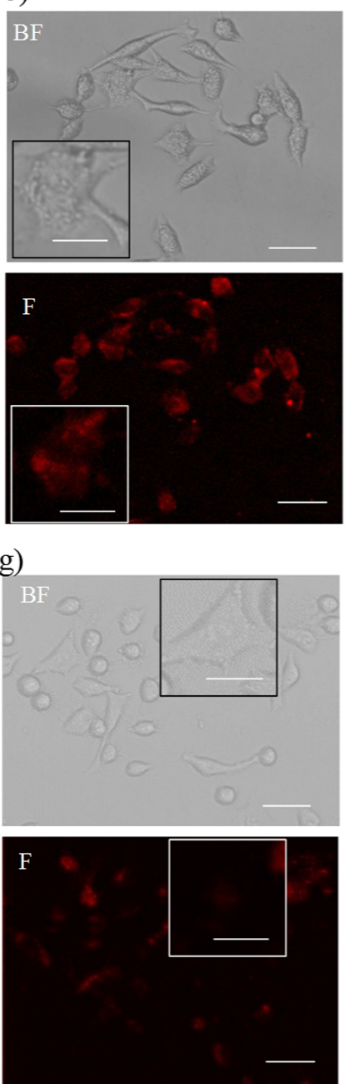

c)
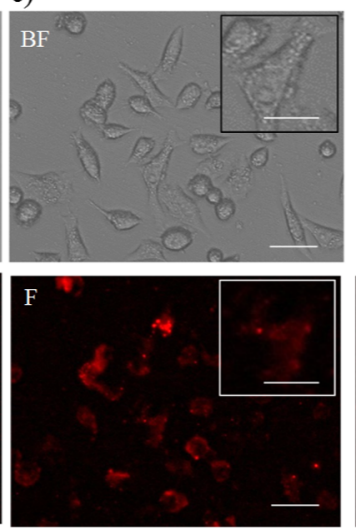

d)


h)

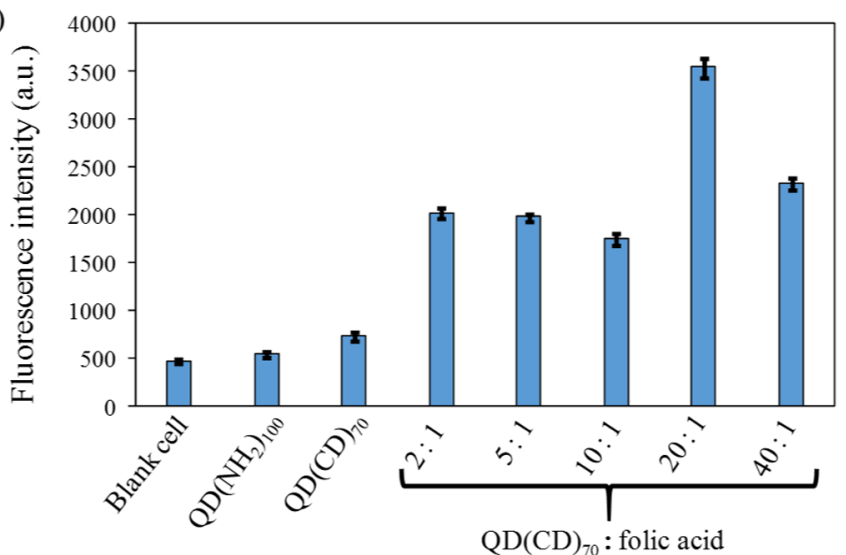

Figure 3. Folate concentration-dependent labeling of $\mathrm{KB}$ cells by $\mathrm{QD}(\mathrm{CD})_{70}$. Colloidal $\mathrm{QD}(\mathrm{CD})_{70}$ is incubated with varied concentrations of folate, where the molar ratio of QD-bound CD to folate is kept at 1 (a), 2 (b), 5 (c), 10 (d), 20 (e), 40 (f), and 70 (g). Next, the cells are incubated with QD samples for $3 \mathrm{~h}$, and the washed cells are used for bright field (BF) or fluorescence (F) imaging. (h) Flow cytometry-based quantitative estimation of QD uptake. About 20000 cells are used for each experiment, and mean \pm SD represents three independent cell-culture replicates $(n=$ 3). Results show that labeling performance is best for the CD to folate molar ratio of 20 . Scale bars are $50 \mu \mathrm{m}$ (main figure) and $25 \mu \mathrm{m}$ (inset).

folate/riboflavin (0.04-1.4 $\mu \mathrm{M})$; we can assume that most of the folate/riboflavin bounds with $\mathrm{CD}$ and the molar ratios of $\mathrm{CD}$ to folate/riboflavin provide the tentative number of folate/ riboflavin bound to each QD. In addition, the folate/riboflavin concentration in human blood ranges from 0.040 to $0.150 \mu \mathrm{M}$, and thus, we may assume a similar situation under in vitro/in vivo conditions.

We have investigated that the fluorescence property of QDs remains stable in the presence of different biological substituents (Supporting Information, Table S1 and Figure S3). In addition, we have investigated the effect of co-existing substances in a complex biological environment and solution $\mathrm{pH}$ on the assembly of the host-guest complex. An insignificant change in the fluorescence intensity suggests that the host-guest complex is stable under a complex bioenvironment (Supporting Information, Table S1 and Figure S4).

Selective Labeling of Cancer Cells Using Folate-/ Riboflavin-Functionalized QDs Prepared via HostGuest Chemistry. We have extensively studied the labeling performance of folate-/riboflavin-functionalized QDs to cancer cells. We have selected $\mathrm{KB}$ cells that over-express folate receptors as well as riboflavin receptors and A431 cells that over-express riboflavin receptors. In addition, we have used Chinese hamster ovary $(\mathrm{CHO})$ cells as control cells that do not over-express folate or riboflavin receptors. The results are summarized in Figures 3-7 and Supporting Information Figures S5-S9, which concludes that folate-functionalized
QDs can selectively label KB cells and riboflavin-functionalized QDs can selectively label A431 and KB cells. To confirm labeling selectivity, we have performed two control experiments. First, $\mathrm{QD}\left(\mathrm{NH}_{2}\right)_{100}$ and $\mathrm{QD}(\mathrm{CD})_{70}$ are used to label $\mathrm{KB} / \mathrm{A} 431$ cells, and the results show that they cannot label cells (Supporting Information, Figure S5). This result is expected as the surface chemistry is appropriately designed with extensive pegylation and overall anionic surface charge. This result also indicates that folate/riboflavin functionalization is necessary for cell labeling. Second, folate-/riboflavin-functionalized QDs are used to label CHO cells that do not have over-expressed folate/ riboflavin receptors. The results show that $\mathrm{CHO}$ cells are not labeled by QD-folate or QD-riboflavin, indicating that the uptake of $\mathrm{QD}$ requires folate/riboflavin receptors on the cell surface (Supporting Information, Figures S6 and S7). In addition, two other control experiments are performed where $\mathrm{KB}$ cells are incubated with a mixture of folate and $\mathrm{QD}\left(\mathrm{NH}_{2}\right)_{100}$ or incubated with folate-functionalized QDs prepared from $\gamma$-CD-functionalized QDs (Supporting Information, Figure S8). In all cases, insignificant cell labeling are observed suggesting that nonspecific binding of folate with $\mathrm{QD}\left(\mathrm{NH}_{2}\right)_{100}$ or poorly interacting $\gamma$-CD host are unable to label cells.

Systematic labeling study shows that there are two critical conditions for cell labeling. First, the labeling is highly sensitive to the molar ratio of QD-bound $\mathrm{CD}$ to folate/riboflavin (Figures 3 and 4 and Supporting Information, Figure S9). We 

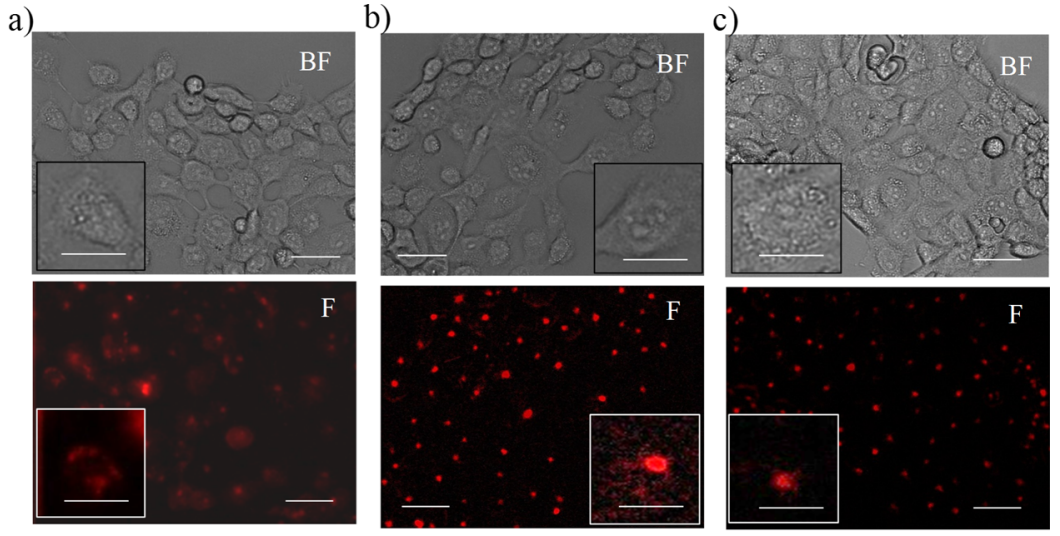

d)



Figure 4. Riboflavin concentration-dependent labeling of $A 431$ cells by $Q D(C D)_{70}$. Colloidal $Q D(C D)_{70}$ is incubated with varied concentrations of riboflavin, where the molar ratio of QD-bound CD to riboflavin is kept at 2 (a), 30 (b), and 50 (c). Next, the cells are incubated with QD samples for $3 \mathrm{~h}$, and the washed cells are used for BF or F imaging. (d) Flow cytometry-based quantitative estimation of QD uptake. About 20000 cells are used for each experiment, and mean \pm SD represents three independent cell-culture replicates $(n=3)$. Results show that labeling performance is best for the $\mathrm{CD}$ to riboflavin molar ratio of 30 . Scale bars are $50 \mu \mathrm{m}$ (main figure) and $25 \mu \mathrm{m}$ (inset).

have used different sets of nanoprobes with the molar ratio of QD-bound CD to folate/riboflavin and found that maximum labeling occurs for the ratio of 20:1 (for folate) or 30:1 (for riboflavin). Under this condition, each $\mathrm{QD}$ is expected to bind with 3 to 4 number of folate/riboflavin (i.e. multivalency of 3 or 4). Labeling becomes inefficient as this molar ratio is either increased or decreased. Second, labeling and subcellular trafficking is highly sensitive to incubation time and continuous incubation for longer time is essential for efficient labeling (Figure 5 and Supporting Information, Figure S10). For example, cellular uptake and subcellular localization of QD are observed under continuous incubation for 1-9 h. By contrast, if shorter incubation time is used followed by further cell growth in fresh culture media, initially labeled QDs detach from the cell surface (Figure 5).

We have quantitatively estimated the cell labeling of QD nanoprobes via flow cytometry. The cells were incubated with QD samples and labeling of QDs is quantified using the fluorescence property of QDs (Figure 3). The results clearly show that labeling is sensitive to the molar ratio of QD-bound $\mathrm{CD}$ to folate/riboflavin and highest for the molar ratio of 20/30 as shown in Figures 3 and 4.

We have also investigated that addition of folic acid in right concentrations into cell culture media leads to the labeling of $\mathrm{KB}$ cells by $\mathrm{QD}(\mathrm{CD})_{70}$, which is otherwise not possible (Supporting Information, Figure S11). This labeling indicates host-guest complexation followed by cell labeling occurring under a complex biological environment.
In another control experiment, we have replaced $\mathrm{CdSe} / \mathrm{ZnS}$ by $\mathrm{Mn}$ doped $\mathrm{ZnS}(\mathrm{Mn}-\mathrm{ZnS})$ and prepared riboflavinfunctionalized $\mathrm{Mn}-\mathrm{ZnS}$ via host-guest chemistry. ${ }^{41}$ In this system, $\mathrm{Mn}-\mathrm{ZnS}$ and riboflavin can be tracked simultaneously, as they have different excitation/emission. Labeled cells are imaged under blue excitation for riboflavin imaging and imaged under UV excitation for $\mathrm{Mn}-\mathrm{ZnS}$ imaging and result show that $\mathrm{Mn}-\mathrm{ZnS}$ and riboflavin are co-localized. This result indicates that the host-guest complex allows the entry of both the nanoparticle host and the riboflavin guest into cells (Supporting Information, Figure S12).

Lipid-Raft Endocytosis and Subcellular Trafficking of Folate-/Riboflavin-Functionalized QDs. We have further investigated the uptake mechanism of QDs using different endocytosis inhibitors. Cells are incubated with folate/ riboflavin free culture medium and inhibitors are added in a required amount. Then, QD samples are added and incubated for another $1.5 \mathrm{~h}$, and washed cells are used for flow cytometrybased quantification of QD uptake. The results show that uptake of QDs differs in the presence of inhibitors. In particular, the uptake of QD-folate and QD-riboflavin is significantly inhibited by methyl- $\beta$-CD (MBCD) and partially inhibited by sucrose (Figure 6). The results clearly suggest that the uptake of nanoprobes occurs predominantly via lipid-raft and partially via clathrin-mediated endocytosis.

We have also observed distinct subcellular localization of QD-folate and QD-riboflavin (Figure 7 and Supporting Information, Figures S13-S15). When QD-folate/QD-riboflavin is incubated with $\mathrm{KB} / \mathrm{A} 431$ cells for $9-10 \mathrm{~h}$, they are 



Figure 5. Incubation time-dependent labeling and subcellular localization of folate-functionalized $\mathrm{QDs}$ in $\mathrm{KB}$ cells. (a) Colloidal $\mathrm{QD}(\mathrm{CD})_{70}$ is incubated with folate, where the molar ratio of QD-bound CD to folate is kept at 20. Next, the cells are incubated with the QD sample for 1-9 h, and then, the washed cells are used for fluorescence (F) imaging. Results show that QD uptake and subcellular localization increase with increased incubation time, and the distinct subcellular localization occurs at $9 \mathrm{~h}$ incubation. (b) Cells are treated with the same QD sample as above but incubated for $3 \mathrm{~h}$, and then, the washed cells are further incubated with fresh media for $6 \mathrm{~h}$ followed by washing and imaging. Results show that the labeled QDs detach from the cell surface after incubation in fresh media. Scale bar represents 20 (a) and $50 \mu \mathrm{m}(\mathrm{b})$.

localized in the perinuclear region and specifically concentrated at one side of the nucleus (Figure 7). High magnification fluorescence images of cells labeled with both nuclear probes and QD-riboflavin and at different $Z$ planes show that QDs localize at the same plane of the nucleus (Supporting Information, Figure S13). The colocalization study with LysoTracker and Golgi tracker shows that QD-folate/QDriboflavin partially localizes at the Golgi apparatus and lysozome (Supporting Information, Figures S14 and S15).

It is well-known that the endocytosis uptake mechanism dictates subcellular trafficking of foreign materials. ${ }^{42,43}$ Clathrinmediated endocytosis usually traffics them to acidic lysosomal/ endosomal compartments but caveolae or lipid-raft mediated endocytosis usually traffics them toward the nucleus, endoplasmic reticulum, and Golgi apparatus. ${ }^{44,45}$ In particular, covalently attached folate-functionalized nanoprobes are reported to enter into cells via both caveolae- and clathrinmediated endocytosis. ${ }^{46-48}$ Similarly, riboflavin-functionalized rhodamine is shown to enter into cells via both caveolae- and clathrin-mediated endocytosis. ${ }^{49}$ We have recently shown that the zwitterionic-lipophilic surface chemistry and $<10$ multivalency of nanoprobes can minimize clathrin-mediated endocytosis and induce predominate caveolae- or lipid-raft endocytosis. ${ }^{44,50}$ In the present case, predominate lipid-raft endocytosis can be explained because of the zwitterionic surface chemistry and 3/4 multivalency of folate-/riboflavin-functionalized QDs that are prepared via the host-guest interaction. This predominate lipid-raft endocytosis ensures their significant trafficking toward the nucleus and Golgi apparatus. To show that these nanoprobes are less toxic, we performed conventional methylthiazolyldiphenyl-tetrazolium bromide (MTT) assay-based cytotoxicity study (Supporting Information, Figure S16). The results show that our nanoprobes are less toxic in the concentration range used for all experiments.

On the basis of our results, we propose the cellular uptake mechanism of folate-/riboflavin-functionalized nanoprobes that is prepared via the host-guest interaction (Scheme 2). At lower folate/riboflavin concentrations, all of them forms inclusion complexes with $\mathrm{CD}$, directs the $\mathrm{QD}$ interaction with folate/ riboflavin receptors at the cell surface, induces endocytosis of QDs, and trafficks QD toward the nucleus/Golgi apparatus. At higher folate/riboflavin concentrations, their fraction is free for competitive interactions with folate/riboflavin receptors at the cell surface that restricts the QD endocytosis. Noncovalent/ modular interaction of folate/riboflavin with $\mathrm{CD}$ helps the easier replacement of their position from $\mathrm{CD}$ to folate/ riboflavin receptors. It is well-established that the hydrophobic cavity of CD encapsulates the hydrophobic phenyl ring of folate and the xylene part of the riboflavin. The remaining parts of folate/riboflavin stay outside of the CD cavity. ${ }^{19,51}$ Also, it is reported that folate and riboflavin can interact with the receptor proteins through the guanidine, hydroxyl groups, and other hydrophobic groups as well. ${ }^{52,53}$ Considering the comparable binding constant $\left(\sim 10^{4} \mathrm{M}^{-1}\right)$ of $\mathrm{CD}$ with riboflavin and tryptophan (through which the riboflavin receptor binds with riboflavin $),{ }^{54}$ it may be assumed that the receptors first bind with the parts of folate/riboflavin which are outside the CD 

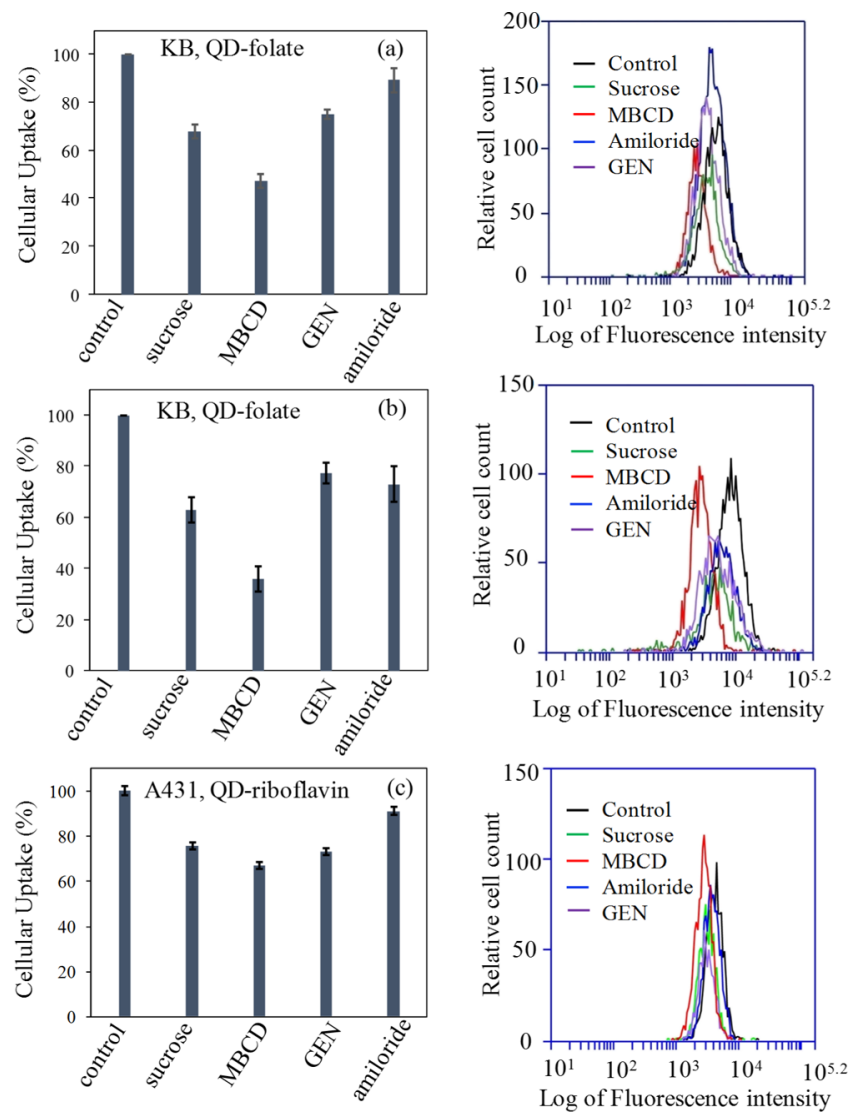

Figure 6. Flow cytometry-based quantitative estimation of QD uptake in $\mathrm{KB}(\mathrm{a}, \mathrm{b})$ and $\mathrm{A} 431$ (c) cells. Colloidal $\mathrm{QD}(\mathrm{CD})_{70}$ is incubated with folate, keeping the molar ratio of QD-bound CD to folate at 20 (a) or 40 (b). Similarly, colloidal $\mathrm{QD}(\mathrm{CD})_{70}$ is incubated with riboflavin, keeping the molar ratio of QD-bound CD to riboflavin at 30 (c). Next, the cells are incubated with endocytosis inhibitors followed by incubation with the QD sample. Next, the washed cells are used for flow cytometry analysis. Result shows that uptake of both QD samples is significantly inhibited by MBCD and partially inhibited by sucrose, which suggests for predominate lipid-raft and partial clathrin-mediated endocytosis. The mean \pm SD represents three independent cell-culture replicates $(n=3)$.

cavity and at the later stage uptaken through equilibrium interactions.

\section{CONCLUSIONS}

We have shown that supramolecular host-guest chemistry can be utilized for functionalization of nanoparticles and targeting cancer cells followed by cellular endocytosis and subcellular trafficking. In particular, we have synthesized folate and riboflavin-functionalized QDs using CD host and demonstrated their labeling and endocytotic uptake into cancer cells with over-expressed folate/riboflavin receptors. As folate and riboflavin receptors are over-expressed in several types of cancer cells, this approach may be extended for in vivo targeting application via simultaneous delivery of host and guest molecules. In addition, the presented functionalization/labeling approach can be extended to other types of host-guest molecules. Compared to the well-known biotin-avidin interaction, a specific biological host-guest interaction, ${ }^{55-57}$ this approach is more general with modular interaction and may find wider application.

\section{EXPERIMENTAL SECTION}

Materials. Cadmium oxide, trioctyl phosphine, trioctyl phosphine oxide, stearic acid, zinc stearate, sulfur powder, selenium powder, poly(ethylene glycol) methacrylate, $\mathrm{N}$-(3aminopropyl)-methacrylamide hydrochloride, 3-sulfopropyl methacrylate, bis [2-(methacryloyloxy)ethyl]phosphate, ammonium persulfate, NHS-PEG-NHS, 3-amino-3-deoxy- $\beta$-cyclodextrin hydrate $\left(\beta-\mathrm{CD}-\mathrm{NH}_{2}\right)$, folic acid, Dulbecco's modified Eagle's medium (DMEM), genistein, amiloride hydrochloride, MBCD, and sucrose were purchased from Sigma-Aldrich and used as received. Folate-free RPMI-1640 medium and riboflavin free Ham's F-12K medium were purchased from Invitrogen. Hoechst, and lysotracker red and NBD C6 ceramide green (Golgi tracker green) were purchased from Life Technology.

Synthesis of $\boldsymbol{\beta}$-Cyclodextrin-Functionalized QDs. Hydrophobic and red emissive $\mathrm{CdSe} / \mathrm{ZnS}$-based QDs were synthesized and made hydrophilic by using the previously reported polyacrylate coating method. ${ }^{11,58}$ First, hydrophobic QDs were dissolved in Igepal-cyclohexane reverse micelles. Next, $0.1 \mathrm{~mL} \mathrm{~N}$-(3-aminopropyl)-methacrylamide hydrochloride (18 $\mathrm{mg}$ dissolved in one $\mathrm{mL}$ water), $0.1 \mathrm{~mL} 3$ sulfopropropyl methacrylate $(228 \mathrm{mg}$ dissolved in one $\mathrm{mL}$ water), $0.1 \mathrm{~mL}$ poly(ethylene glycol) methacrylate $(360 \mu \mathrm{L}$ dissolved in one $\mathrm{mL}$ water), and $100 \mu \mathrm{L}$ bis[2(methacryloyloxy)ethyl]phosphate $(60 \mu \mathrm{L}$ dissolved in one $\mathrm{mL}$ water) were added. Next, polymerization was initiated under nitrogen atmosphere with the addition of $0.1 \mathrm{~mL}$ of persulfate solution ( $35 \mathrm{mg}$ dissolved in one $\mathrm{mL}$ water). After 30 min of polymerization, QDs were precipitated by adding ethanol, and the particles were washed repeatedly with chloroform and ethanol and finally dissolved in water.

Functionalization with $\beta$-CD was performed using NHSPEG-NHS-based conjugation chemistry. Typically, $100 \mu \mathrm{L}$ DMF solution of NHS-PEG-NHS $(4.6 \mathrm{mg} / \mathrm{mL})$ was mixed with $100 \mu \mathrm{L}$ borate buffer solution ( $\mathrm{pH}$ 9.0) of $\beta$-CD-NH $(11.3 \mathrm{mg} / \mathrm{mL})$. The mixture was shaken for $2-3 \mathrm{~min}$, and then, the whole solution was added to $1-2 \mathrm{~mL}$ QDs solution and stirred for $4-5 \mathrm{~h}$ at room temperature. Next, the solution was dialyzed against fresh water for 1 day and used as the stock solution.

Estimation of $\beta$-Cyclodextrin in Functionalized QDs. Detection and quantification of QD-bound $\beta$-CDs were performed by the anthrone test. ${ }^{59}$ The anthrone test was performed using different concentrations of $\beta-\mathrm{CD}-\mathrm{NH}_{2}$. Typically, a stock solution of anthrone was prepared by dissolving $4 \mathrm{mg}$ anthrone in $2 \mathrm{~mL}$ of $80 \%$ sulfuric acid. Next, $150 \mu \mathrm{L}$ of $\beta-\mathrm{CD}-\mathrm{NH}_{2}$ solution was added to it, heated in boiling water bath for 10-15 min, and cooled in ice bath, and the absorbance at $620 \mathrm{~nm}$ was measured. A linear calibration curve was obtained by plotting the absorbance with respect to the concentration of $\beta-\mathrm{CD}-\mathrm{NH}_{2}$. The linear equation was obtained as follows: $Y=2.5 \times 10^{4} X+0.1$ with $R^{2}=0.99$. $(X=$ concentration of $\beta-\mathrm{CD}-\mathrm{NH}_{2}$ and $Y=$ absorbance at $\left.620 \mathrm{~nm}\right)$.

Similarly, the anthrone test was done using CD-functionalized QDs, and the absorbance was measured at $620 \mathrm{~nm}$ and the amount of $\beta$-CD is determined from the above-mentioned calibration graph. Separately, the concentration of QDs in CDfunctionalized QDs was measured by using the QD absorbance at $573 \mathrm{~nm} .{ }^{40}$ Next, the number of $\mathrm{CD}$ per $\mathrm{QD}$ has been determined from the molar ratio of $\mathrm{CD}$ and $\mathrm{QDs}$, and the average value is $70 \pm 5$. This result was further supported from the GPC-based molecular weight study. The molecular weight 



Figure 7. Subcellular localization of folate-functionalized QDs in KB cells (a) and riboflavin-functionalized QDs in A431 cells (b) and KB cells (c). Colloidal $\mathrm{QD}(\mathrm{CD})_{70}$ is incubated with folate, keeping the molar ratio of QD-bound $\mathrm{CD}$ to folate at 20 for the preparation of folate-functionalized QDs. Similarly, colloidal $\mathrm{QD}(\mathrm{CD})_{70}$ is incubated with riboflavin, keeping the molar ratio of QD-bound CD to riboflavin at 30 for the preparation of riboflavin-functionalized QD. Next, the cells are incubated with the QD sample for $9 \mathrm{~h}$ (for folate-functionalized QDs in KB cells) or $3 \mathrm{~h}$ (for riboflavin-functionalized QDs) in respective cells followed by incubation with nuclear probes for $30 \mathrm{~min}$, and the washed cells are used for imaging under BF or F mode. Results show that QDs are localized in the perinuclear region and concentrated at one side of the nucleus. Red color corresponds to QDs and blue color corresponds to nuclear probes. Scale bar represents $50 \mu \mathrm{m}$.

Scheme 2. Proposed Endocytosis Mechanism of Folate-/Riboflavin-Functionalized QDs Prepared via Supramolecular HostGuest Chemistry $^{a}$

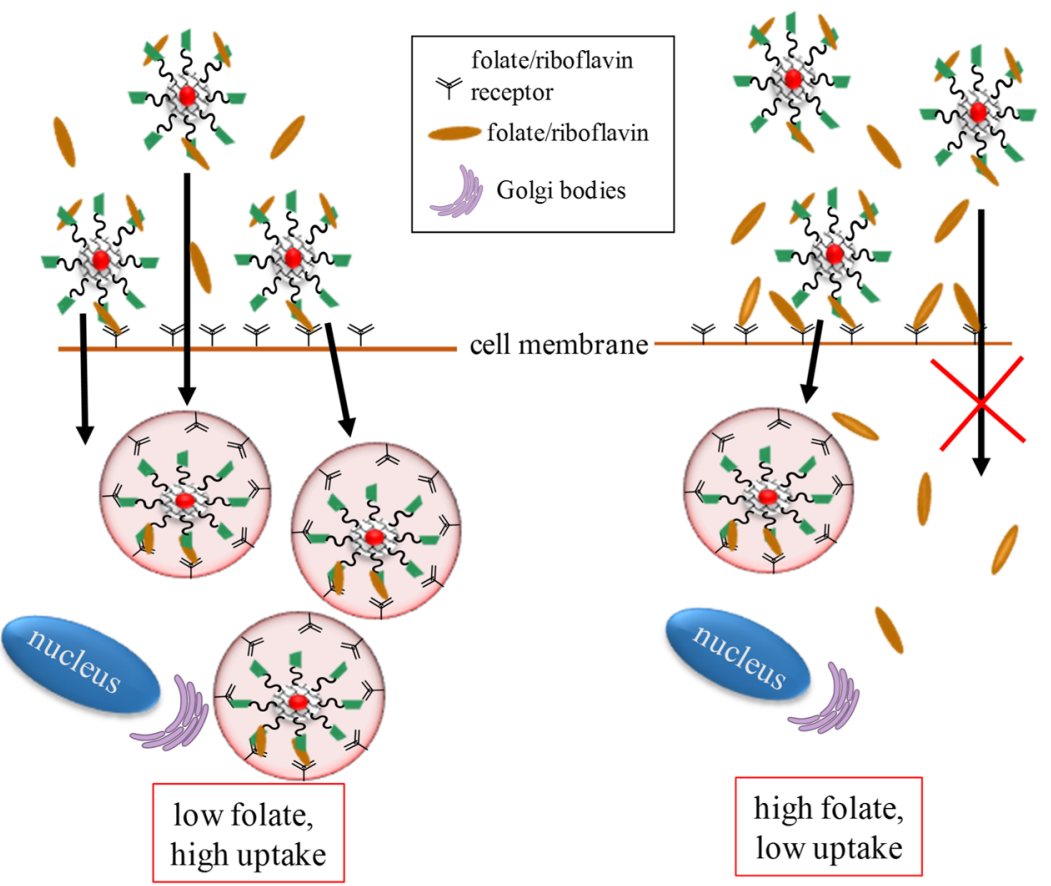

${ }^{a}$ At lower folate/riboflavin concentrations, all of them forms an inclusion complex with $\mathrm{CD}$, directs the QD interaction with folate/riboflavin receptors at the cell surface, induces lipid-raft endocytosis of QDs, and traffics QDs toward the perinuclear region. At higher folate/riboflavin concentrations, a significant fraction of them are free for competitive interaction with folate/riboflavin receptors and restrict $\mathrm{QD}$ endocytosis.

of $\mathrm{QD}\left(\mathrm{NH}_{2}\right)_{100}$ was determined before and after $\mathrm{CD}$ conjugation and increased molecular weight of $90 \mathrm{kDa}$ was accounted for $\sim 70 \mathrm{CD}$. Thus, the CD-functionalized QDs were abbreviated as $\mathrm{QD}(\mathrm{CD})_{70}$.
Preparation of Folate- and Riboflavin-Functionalized QDs via the Host-Guest Interaction. Aqueous solutions of $\mathrm{QD}(\mathrm{CD})_{70}$ (with the $\mathrm{CD}$ concentration of $10^{-4} \mathrm{M}$ ), DMF solution of folic acid $\left(6 \times 10^{-4} \mathrm{M}\right)$ and aqueous solution of riboflavin $\left(10^{-4} \mathrm{M}\right)$ were prepared separately. Next, seven sets 
of $\mathrm{QD}(\mathrm{CD})_{70}$ were prepared each having $1 \mathrm{~mL}$ solution. Next, 5-20 $\mu \mathrm{L}$ folic acid/riboflavin solution was added to each sets such that the molar ratio of $\mathrm{CD}$ to that of the folic acid/ riboflavin was varied from 70 to 1 . Solutions of each set were stirred overnight and preserved at room temperature under darkness. Similar types of sets were also prepared using $\mathrm{QD}(\mathrm{CD})_{70}$ but $\mathrm{QD}$ fluorescence was quenched by adding concentrated $\mathrm{HCl}$ followed by neutralizing the solution with $\mathrm{NaOH}$. Other control sets were prepared using $\beta-\mathrm{CD}-\mathrm{NH}_{2}$ instead of using $\mathrm{QD}(\mathrm{CD})_{70}$.

Study of Host-Guest Complexation between QD$(C D)_{70}$ and Folic Acid/Riboflavin. First, seven experimental sets were prepared using $\mathrm{QD}(\mathrm{CD})_{70}$ ( or $\beta-\mathrm{CD}-\mathrm{NH}_{2}$ ), by varying the $\mathrm{CD}$ to folic acid molar ratio from 70 to 1 . Next, $\mathrm{QD}$ fluorescence was quenched by adding concentrated $\mathrm{HCl}$ followed by neutralizing the solution with $\mathrm{NaOH}$. Next, absorption spectra were measured to note the absorbance value at 360 and $280 \mathrm{~nm}$, and the emission spectra were measured (with $370 \mathrm{~nm}$ excitation) to note the emission intensity at $455 \mathrm{~nm}$. Similarly, seven experimental sets were prepared using $\mathrm{QD}(\mathrm{CD})_{70}$ ) ( or $\beta-\mathrm{CD}-\mathrm{NH}_{2}$ ), by varying the $\mathrm{CD}$ to riboflavin molar ratio from 70 to 1 . Next, QD fluorescence was quenched by adding concentrated $\mathrm{HCl}$ followed by neutralizing the solution with $\mathrm{NaOH}$. Next, absorption spectra were measured to note the absorbance of riboflavin at 445 and $370 \mathrm{~nm}$.

Cell Labeling Study. Here, in this experiment, KB cells were used as folate and riboflavin receptor over-expressed cells and A431 cells were used as riboflavin receptor over-expressed cells. $\mathrm{CHO}$ was used as control cells that does not have overexpressed folate or riboflavin receptors. Cells were cultured overnight in 24-well plates before experiments. $\mathrm{KB}$ cells were cultured in folate-free RPMI-1640 (Invitrogen) with 10\% heatactivated fetal bovine serum and $1 \%$ penicillin streptomycin at $37{ }^{\circ} \mathrm{C}$ and $5 \% \mathrm{CO}_{2}$ atmosphere. A431 cells were cultured in riboflavin free $\mathrm{F}-12 \mathrm{~K}$ (Invitrogen) medium, and $\mathrm{CHO}$ cells were cultured in DMEM (Sigma), RPMI, and F-12K (Invitrogen) media with all other conditions similar to the previous one. Next, 50-100 $\mu \mathrm{L}$ QD-folate/QD-riboflavin solution was added followed by $1-9 \mathrm{~h}$ incubation. Next, the cells were washed with phosphate-buffered saline (PBS) buffer, and the images were taken by adding fresh medium. The tentative concentration range of $\mathrm{QDs}, \mathrm{CD}$, folate, and riboflavins used was $0.1-1.0,7-70,0.04-1.4$, and 0.04-1.4 $\mu \mathrm{M}$, respectively.

For the quantitative estimation of cellular uptake, we performed flow cytometry-based study. Cells were separately incubated with $\mathrm{QD}\left(\mathrm{NH}_{2}\right)_{100}, \mathrm{QD}(\mathrm{CD})_{70}$, and folate-/riboflavin-functionalized QDs for $3 \mathrm{~h}$ and washed with PBS buffer. Then, the cells were treated with trypsin-ethylenediaminetetraacetic acid (EDTA) solution to detach them from the plate. Finally, the detached cells were isolated by centrifugation and redispersed in PBS buffer, and the emission property of QDs under blue excitation is used for quantification. About 20000 cells were used in each experiment, and each experiment is performed three independent cell-culture replicates.

Colocalization Study. KB and A431 cells were cultured in a four-well chamber slides for $24 \mathrm{~h}$ in their respective culture media. Cells were incubated with QD-folate and QD-riboflavin for 9-10 h for cellular uptake. Next, cells were washed with PBS buffer, fresh medium was added, and images were taken. Next, cells were incubated with lysotracker red and Golgi tracker green for $30 \mathrm{~min}$, and the washed cells were used for the imaging study. Further cells were fixed using $4 \%$ paraformaldehyde, and the fixed cells were used for imaging.

Endocytosis Inhibition Study. To investigate the endocytosis mechanism, cells were cultured in their respective media, pretreated with different endocytosis inhibitors of appropriate concentrations for $1 \mathrm{~h}$, and finally incubated with QD-folate or QD-riboflavin samples for $90 \mathrm{~min}$. We have used MBCD to block the lipid-raft-mediated endocytosis mechanism, genistein to block caveolae-mediated endocytosis, sucrose to inhibit clathrin-mediated endocytosis, and amiloride to inhibit macropinocytosis. Next, the cells were washed with PBS buffer to remove unbound QD. Then, the cells were treated with trypsin-EDTA solution to detach them from the plate. Finally, the detached cells were isolated by centrifugion and dispersed in PBS buffer for the flow cytometry study.

Cell Viability Assay. KB cells were cultured in 24-well plates in the cell culture medium. After that, cells were treated with the QD sample for $24 \mathrm{~h}$ and then washed through PBS buffer, and fresh DMEM medium was added. Then, $50 \mu \mathrm{L}$ of freshly prepared MTT solution $(5 \mathrm{mg}$ MTT in $1 \mathrm{~mL}$ deionized water) was added to each well and incubated for 4-5 h. Next, the supernatant was removed and formazon was dissolved in sodium dodecyl sulfate (SDS) solution (8 $\mathrm{g}$ of SDS dissolved in $40 \mathrm{~mL}$ of $\mathrm{DMF}-\mathrm{H}_{2} \mathrm{O}$ mixture), and the absorbance was measured at $570 \mathrm{~nm}$.

Instrumentation. UV-visible absorption spectral studies were carried out with a Shimadzu UV-2550 spectrophotometer. A Malvern Nano ZS instrument was used to measure the DLS size and zeta potential. GPC (Waters 515) equipped with Waters HSP gel columns was used for the determination of the molecular weight. The TEM study was carried out on an FEI Tecnai G2 F20 microscope, fluorescence measurements were performed using a Synergy Mx microplate reader (BioTek) and a PerkinElmer LS 45, and fluorescence images of cells were captured by using an Olympus IX 81 microscope using ImagePro Plus 7.0 software. Fluorescence-based quantification was studied using a BD Accuri C6 flow cytometer.

\section{ASSOCIATED CONTENT}

\section{Supporting Information}

The Supporting Information is available free of charge on the ACS Publications website at DOI: 10.1021/acsomega.7b01506.

Details of the endocytosis inhibitor concentration, properties of functional nanoparticles, control celllabeling experiments, and additional experimental results (PDF)

\section{AUTHOR INFORMATION}

\section{Corresponding Author}

*E-mail: camnrj@iacs.res.in (N.R.J.).

ORCID $\odot$

Suman Pal: 0000-0003-3852-4857

Chumki Dalal: 0000-0003-0098-1884

Nikhil R. Jana: 0000-0002-4595-6917

Notes

The authors declare no competing financial interest.

\section{ACKNOWLEDGMENTS}

The authors acknowledge CSIR, Government of India for financial assistance. (no. 02(0249)/15/EMR-II) S.P. and C.D. acknowledge CSIR, India for providing research fellowship. 


\section{REFERENCES}

(1) Katz, E.; Willner, I. Integrated Nanoparticle-Biomolecule Hybrid Systems: Synthesis, Properties, and Applications. Angew. Chem., Int. Ed. 2004, 43, 6042-6108.

(2) Rosi, N. L.; Mirkin, C. A. Nanostructures in Biodiagnostics. Chem. Rev. 2005, 105, 1547-1562.

(3) Medintz, I. L.; Uyeda, H. T.; Goldman, E. R.; Mattoussi, H. Quantum Dot Bioconjugates for Imaging, Labelling and Sensing. Nat. Mater. 2005, 4, 435-446.

(4) Slowing, I. I.; Vivero-Escoto, J. L.; Wu, C.-W.; Lin, V. S. Y. Mesoporous Silica Nanoparticles as Controlled Release Drug Delivery and Gene Transfection Carriers. Adv. Drug Delivery Rev. 2008, 60, $1278-1288$.

(5) Murphy, C. J.; Gole, A. M.; Stone, J. W.; Sisco, P. N.; Alkilany, A. M.; Goldsmith, E. C.; Baxter, S. C. Gold Nanoparticles in Biology: Beyond Toxicity to Cellular Imaging. Acc. Chem. Res. 2008, 41, 17211730.

(6) De, M.; Ghosh, P. S.; Rotello, V. M. Applications of Nanoparticles in Biology. Adv. Mater. 2008, 20, 4225-4241.

(7) Bilan, R.; Fleury, F.; Nabiev, I.; Sukhanova, A. Quantum Dot Surface Chemistry and Functionalization for Cell Targeting and Imaging. Bioconjugate Chem. 2015, 26, 609-624.

(8) Jana, N. R. Design and Development of Quantum Dots and other Nanoparticles based Cellular Imaging Probe. Phys. Chem. Chem. Phys. 2011, 13, 385-396.

(9) Sapsford, K. E.; Algar, W. R.; Berti, L.; Gemmill, K. B.; Casey, B. J.; Oh, E.; Stewart, M. H.; Medintz, I. L. Functionalizing Nanoparticles with Biological Molecules: Developing Chemistries that Facilitate Nanotechnology. Chem. Rev. 2013, 113, 1904-2074.

(10) Wang, W.; Ji, X.; Burns, H.; Mattoussi, H. A Multi-coordinating Polymer Ligand Optimized for the Functionalization of Metallic Nanocrystals and Nanorods. Faraday Discuss. 2016, 191, 481-494.

(11) Saha, A.; Basiruddin, S. K.; Maity, A. R.; Jana, N. R. Synthesis of Nanobioconjugates with a Controlled Average Number of Biomolecules between 1 and 100 per Nanoparticle and Observation of Multivalency Dependent Interaction with Proteins and Cells. Langmuir 2013, 29, 13917-13924.

(12) Park, J.; Brust, T. F.; Lee, H. J.; Lee, S. C.; Watts, V. J.; Yeo, Y. Polydopamine-Based Simple and Versatile Surface Modification of Polymeric Nano Drug Carriers. ACS Nano 2014, 8, 3347-3356.

(13) Mizuhara, T.; Moyano, D. F.; Rotello, V. M. Using the Power of Organic Synthesis for Engineering the Interactions of Nanoparticles with Biological Systems. Nano Today 2016, 11, 31-40.

(14) Georgakilas, V.; Tiwari, J. N.; Kemp, K. C.; Perman, J. A.; Bourlinos, A. B.; Kim, K. S.; Zboril, R. Noncovalent Functionalization of Graphene and Graphene Oxide for Energy Materials, Biosensing, Catalytic, and Biomedical Applications. Chem. Rev. 2016, 116, 54645519.

(15) Hu, P.; Chen, L.; Kang, X.; Chen, S. Surface Functionalization of Metal Nanoparticles by Conjugated Metal-Ligand Interfacial Bonds: Impacts on Intraparticle Charge Transfer. Acc. Chem. Res. 2016, 49, 2251-2260.

(16) González-Campo, A.; Hsu, S.-H.; Puig, L.; Huskens, J.; Reinhoudt, D. N.; Velders, A. H. Orthogonal Covalent and Noncovalent Functionalization of Cyclodextrin-Alkyne Patterned Surfaces. J. Am. Chem. Soc. 2010, 132, 11434-11436.

(17) Dorokhin, D.; Hsu, S.-H.; Tomczak, N.; Reinhoudt, D. N.; Huskens, J.; Velders, A. H.; Vancso, G. J. Fabrication and Luminescence of Designer Surface Patterns with $\beta$-Cyclodextrin Functionalized Quantum Dots via Multivalent Supramolecular Coupling. ACS Nano 2010, 4, 137-142.

(18) Lee, D.-W.; Park, K. M.; Banerjee, M.; Ha, S. H.; Lee, T.; Suh, K.; Paul, S.; Jung, H.; Kim, J.; Selvapalam, N.; Ryu, S. H.; Kim, K. Supramolecular Fishing for Plasma Membrane Proteins Using an Ultrastable Synthetic Host-Guest Binding Pair. Nat. Chem. 2011, 3, 154-159.

(19) Zhao, M.-X.; Huang, H.-F.; Xia, Q.; Ji, L.-N.; Mao, Z.-W. $\gamma$ Cyclodextrin-Folate Complex-Functionalized Quantum Dots for
Tumor-Targeting and Site-Specific Labeling. J. Mater. Chem. 2011, 21, 10290-10297.

(20) Jin, H.; Liu, Y.; Zheng, Y.; Huang, W.; Zhou, Y.; Yan, D. Cytomimetic Large-Scale Vesicle Aggregation and Fusion Based on Host-Guest Interaction. Langmuir 2012, 28, 2066-2072.

(21) Agasti, S. S.; Liong, M.; Tassa, C.; Chung, H. J.; Shaw, S. Y.; Lee, H.; Weissleder, R. Supramolecular Host-Guest Interaction for Labeling and Detection of Cellular Biomarkers. Angew. Chem., Int. Ed. 2012, 51, $450-454$.

(22) Mathew, A.; Natarajan, G.; Lehtovaara, L.; Häkkinen, H.; Kumar, R. M.; Subramanian, V.; Jaleel, A.; Pradeep, T. Supramolecular Functionalization and Concomitant Enhancement in Properties of Au25 Clusters. ACS Nano 2014, 8, 139-152.

(23) Himiyama, T.; Onoda, A.; Hayashi, T. Photochemical Property of a Myoglobin-CdTe Quantum Dot Conjugate formed by Supramolecular Host-Guest Interactions. Chem. Lett. 2014, 43, $1152-1154$

(24) Liu, T.; Shi, F.; Boussouar, I.; Zhou, J.; Tian, D.; Li, H. Liquid Quantum Dots Constructed by Host-Guest Interaction. ACS Macro Lett. 2015, 4, 357-360.

(25) Han, J.; Gao, C. Host-Guest Supramolecular Chemistry of Dendritic Macromolecules. Curr. Org. Chem. 2011, 15, 2-26.

(26) Ma, X.; Zhao, Y. Biomedical Applications of Supramolecular Systems Based on Host-Guest Interactions. Chem. Rev. 2015, 115, 7794-7839.

(27) Dong, R.; Zhou, Y.; Zhu, X. Supramolecular Dendritic Polymers: From Synthesis to Applications. Acc. Chem. Res. 2014, 47, 2006-2016.

(28) Zhang, J.; Ma, P. X. Cyclodextrin-based Supramolecular Systems for Drug Delivery: Recent Progress and Future Perspective. Adv. Drug Delivery Rev. 2013, 65, 1215-1233.

(29) Zhang, Y.; Ren, L.; Tu, Q.; Wang, X.; Liu, R.; Li, L.; Wang, J.-C.; Liu, W.; Xu, J.; Wang, J. Fabrication of Reversible Poly(dimethylsiloxane) Surfaces via Host-Guest Chemistry and Their Repeated Utilization in Cardiac Biomarker Analysis. Anal. Chem. 2011, 83, 9651-9659.

(30) Soum, C.; Rubio-Albenque, S.; Fery-Forgues, S.; Déléris, G.; Alouini, M.-A.; Berthelot, T. Supramolecular Peptide/Surface Assembly for Monitoring Proteinase Activity and Cancer Diagnosis. ACS Appl. Mater. Interfaces 2015, 7, 16967-16975.

(31) Xue, M.; Wei, W.; Su, Y.; Johnson, D.; Heath, J. R. Supramolecular Probes for Assessing Glutamine Uptake Enable Semi-Quantitative Metabolic Models in Single Cells. J. Am. Chem. Soc. 2016, 138, 3085-3093.

(32) Lu, Y.; Low, P. S. Folate-Mediated Delivery of Macromolecular Anticancer Therapeutic Agents. Adv. Drug Delivery Rev. 2002, 54, 675-693.

(33) Bareford, L. M.; Avaritt, B. R.; Ghandehari, H.; Nan, A.; Swaan, P. W. Riboflavin-Targeted Polymer Conjugates for Breast Tumor Delivery. Pharm. Res. 2013, 30, 1799-1812.

(34) Yang, B.; Dong, X.; Lei, Q.; Zhuo, R.; Feng, J.; Zhang, X. HostGuest Interaction-Based Self-Engineering of Nano-Sized Vesicles for Co-Delivery of Genes and Anticancer Drugs. ACS Appl. Mater. Interfaces 2015, 7, 22084-22094.

(35) Okamatsu, A.; Motoyama, K.; Onodera, R.; Higashi, T.; Koshigoe, T.; Shimada, Y.; Hattori, K.; Takeuchi, T.; Arima, H. FolateAppended $\beta$-Cyclodextrin as a Promising Tumor Targeting Carrier for Antitumor Drugs in Vitro and in Vivo. Bioconjugate Chem. 2013, 24, 724-733.

(36) Zhao, F.; Yin, H.; Zhang, Z.; Li, J. Folic Acid Modified Cationic $\gamma$-Cyclodextrin-oligoethylenimine Star Polymer with Bioreducible Disulfide Linker for Efficient Targeted Gene Delivery. Biomacromolecules 2013, 14, 476-484.

(37) Loukas, Y. L.; Vraka, V.; Gregoriadis, G. Fluorimetric Studies of the Formation of Riboflavin- $\beta$-Cyclodextrin Inclusion Complex: Determination of the Stability Constant by use of a Non-linear Least-squares Model. J. Pharm. Pharmacol. 1997, 49, 127-130. 
(38) Roy, D. K.; Deb, N.; Ghosh, B. C.; Mukherjee, A. K. Inclusion of Riboflavin in $\beta$-Cyclodextrin: A Fluorimetric and Absorption Spectrometric Study. Spectrochim. Acta, Part A 2009, 73, 201-204.

(39) Ceborska, M.; Zimnicka, M.; Wszelaka-Rylik, M.; Troć, A. Characterization of Folic Acid/Native Cyclodextrins Host-Guest Complexes in Solution. J. Mol. Struct. 2016, 1109, 114-118.

(40) Yu, W. W.; Qu, L.; Guo, W.; Peng, X. Experimental Determination of the Extinction Coefficient of $\mathrm{CdTe}, \mathrm{CdSe}$, and CdS Nanocrystals. Chem. Mater. 2003, 15, 2854-2860.

(41) Maity, A. R.; Palmal, S.; Basiruddin, S. K.; Karan, N. S.; Sarkar, S.; Pradhan, N.; Jana, N. R. Doped Semiconductor Nanocrystal based Fluorescent Cellular Imaging Probes. Nanoscale 2013, 5, 5506-5513.

(42) Mayor, S.; Pagano, R. E. Pathways of Clathrin-Independent Endocytosis. Nat. Rev. Mol. Cell Biol. 2007, 8, 603-612.

(43) Johannes, L.; Parton, R. G.; Bassereau, P.; Mayor, S. Building Endocytic Pits without Clathrin. Nat. Rev. Mol. Cell Biol. 2015, 16, 311-321.

(44) Chakraborty, A.; Jana, N. R. Clathrin to Lipid Raft-Endocytosis via Controlled Surface Chemistry and Efficient Perinuclear Targeting of Nanoparticle. J. Phys. Chem. Lett. 2015, 6, 3688-3697.

(45) Rejman, J.; Bragonzi, A.; Conese, M. Role of Clathrin- and Caveolae-mediated Endocytosis in Gene Transfer Mediated by Lipoand Polyplexes. Mol. Ther. 2005, 12, 468-474.

(46) Suen, W.-L. L.; Chau, Y. Size-Dependent Internalisation of Folate-Decorated Nanoparticles via the Pathways of Clathrin and Caveolae-Mediated Endocytosis in ARPE-19 Cells. J. Pharm. Pharmacol. 2013, 66, 564-573.

(47) Li, Y.-L.; Van Cuong, N.; Hsieh, M.-F. Endocytosis Pathways of the Folate Tethered Star-Shaped PEG-PCL Micelles in Cancer Cell Lines. Polymers 2014, 6, 634-650.

(48) Cao, D.; Tian, S.; Huang, H.; Chen, J.; Pan, S. Divalent Folate Modification on PEG: An Effective Strategy for Improving the Cellular Uptake and Targetability of PEGylated Polyamidoamine-Polyethylenimine Copolymer. Mol. Pharmaceutics 2015, 12, 240-252.

(49) Foraker, A. B.; Ray, A.; Da Silva, T. C.; Bareford, L. M.; Hillgren, K. M.; Schmittgen, T. D.; Swaan, P. W. Dynamin 2 Regulates Riboflavin Endocytosis in Human Placental Trophoblasts. Mol. Pharmacol. 2007, 72, 553-562.

(50) Dalal, C.; Saha, A.; Jana, N. R. Nanoparticle Multivalency Directed Shifting of Cellular Uptake Mechanism. J. Phys. Chem. C 2016, 120, 6778-6786.

(51) Loukas, Y. L.; Vraka, V.; Gregoriadis, G. Fluorimetric Studies of the Formation of Riboflavin- $\beta$-Cyclodextrin Inclusion Complex: Determination of the Stability Constant by use of a Non-linear Least-squares Model. J. Pharm. Pharmacol. 1997, 49, 127-130.

(52) Chen, C.; Ke, J.; Zhou, X. E.; Yi, W.; Brunzelle, J. S.; Li, J.; Young, E.-L.; Xu, H. E.; Melcher, K. Structural Basis for Molecular Recognition of Folic Acid by Folate Receptors. Nature 2013, 500, 486-489.

(53) Monaco, H. L. Crystal Structure of Chicken Riboflavin-Binding Protein. EMBO J. 1997, 16, 1475-1483.

(54) Kamat, B. P.; Seetharamappa, J.; Melwanki, M. B. Spectroscopic Studies on the Interaction of Riboflavin with Bovine Serum Albumin. Indian J. Biochem. Biophys. 2004, 41, 173-178.

(55) Lingerfelt, B. M.; Mattoussi, H.; Goldman, E. R.; Mauro, J. M.; Anderson, G. P. Preparation of Quantum Dot-Biotin Conjugates and Their Use in Immunochromatography Assays. Anal. Chem. 2003, 75, 4043-4049.

(56) Mittal, R.; Bruchez, M. P. Biotin-4-Fluorescein Based Fluorescence Quenching Assay for Determination of Biotin Binding Capacity of Streptavidin Conjugated Quantum Dots. Bioconjugate Chem. 2011, 22, 362-368.

(57) Wilchek, M.; Bayer, E. A. The Avidin-Biotin Complex in Bioanalytical Applications. Anal. Biochem. 1988, 171, 1-32.

(58) Basiruddin, S. K.; Saha, A.; Pradhan, N.; Jana, N. R. Advances in Coating Chemistry in Deriving Soluble Functional Nanoparticle. J. Phys. Chem. C 2010, 114, 11009-11017.
(59) Turula, V. E.; Gore, T.; Singh, S.; Arumugham, R. G. Automation of the Anthrone Assay for Carbohydrate Concentration Determinations. Anal. Chem. 2010, 82, 1786-1792. 